\title{
Viral challenge in leprosy: viraemia, interferon, and specific antibody production
}

\author{
R H GELBER, ${ }^{*} \S$ H C GOOI, ${ }^{*}$ J S PORTERFIELD, $\dagger$ \\ $\mathrm{S}$ K LAM $\ddagger \& \mathrm{R} \mathrm{J}$ W REES $\dagger$ \\ *National Leprosy Control Center, Sungei Buloh, Malaysia; \\ $\dagger$ National Institute for Medical Research, London, England; \\ $\ddagger$ University of Malaya.
}

Accepted for publication 16 September 1986

\begin{abstract}
Summary Following 17-D yellow fever vaccination, viraemia and specific neutralizing antibody production were assessed in groups of 12 healthy Malay controls and Malay tuberculoid and lepromatous leprosy patients. Subsequent viraemia was found in 10 healthy subjects, 9 tuberculoid patients and 8 lepromatous patients. Neither the time of appearance, chronicity, nor titre of viraemia was different amongst the three groups. Nine or 10 individuals from each of the 3 subject groups developed specific neutralizing antibody. Prior to vaccination, the ability of peripheral blood leucocytes to produce interferon in vitro after stimulation with Newcastle Disease Virus, was studied. Leucocytes from all the healthy subjects and patients produced significant amounts of interferon. Neither lepromatous nor tuberculoid patients' leucocytes produced levels of interferon different from healthy controls. A tendency was observed for lepromatous patients to produce decreased amounts of interferon in vitro as compared to tuberculoid patients $(P=0 \cdot 06)$.
\end{abstract}

\section{Introduction}

Clinicians generally agree, and a number of studies have supported the view, that leprosy patients appear to handle other infections normally and are not predisposed to immunologically mediated disease or malignancy. ${ }^{2-4}$ As a prerequisite for leprosy vaccines to prove effective, individuals at risk in endemic countries should be capable of responding in a normal fashion to unrelated infectious agents. In order to experimentally test this issue, we performed a study in Malaysia utilizing well classified lepromatous and tuberculoid patients and healthy controls, which assessed in vitro leucocyte interferon production and in

§Correspondence to: Seton Medical Center, 1900 Sullivan Ave., Daly City, CA 94015, USA. 
vivo viraemia and specific neutralizing antibody development, following the challenge of subjects with a non-endemic virus, live attenuated yellow fever.

\section{Materials and methods}

\section{SUBJECTS}

Subjects included 12 healthy Malay staff members of the National Leprosy Control Center, Sungei Buloh, Malaysia, 12 Malay lepromatous leprosy patients, and 12 Malay tuberculoid leprosy patients. None of the subjects had a prior history of yellow fever vaccination, encephalitis, dengue or travel outside Malaysia. Disease classification was based on clinical and histologic findings (Ridley, D.S.) and lepromin skin testing. Subjects were vaccinated subcutaneously with $0.5 \mathrm{cc}$ of a 17-D vaccine strain of yellow fever. Viraemia was assessed prior to vaccination and 4 or 5 days, and in some instances 6 days later, and circulating neutralizing antibody were determined and quantitated prior to vaccination and 4,5 and 12 days later. Prior to vaccination, the ability of peripheral blood leucocytes to produce interferon in vitro was assessed.

VIR AEMIA

Viraemia following yellow fever vaccination was assayed in pig kidney (PS) cells grown in Leibovitz L 15 medium with 3\% inactivated foetal calf serum following the method of Madrid and Porterfield ${ }^{5}$ with minor modifications. Undiluted human serum was added to a suspension of $3 \times 10^{5} \mathrm{PS}$ cells $/ \mathrm{ml}$, using $0.1 \% \mathrm{ml}$ serum to $2.5 \mathrm{ml}$ cells in one $50 \mathrm{~mm}$ plastic petri dish or $0.05 \mathrm{ml}$ serum to $0.5 \mathrm{ml}$ cells in each of two wells in disposable FB-16-24 plastic containers, and cultures were overlaid with an equal volume of carboxymethyl cellulose overlay $2 \mathrm{~h}$ later. After 5 (or occasionally 7) days incubation at $35^{\circ} \mathrm{C}$, preparations were rinsed with normal saline, stained with naphthalene black, and any plaques visible were counted.

\section{YELLOW FEVER ANTIBODY}

Neutralization tests were performed in disposable plastic trays. One volume $(0 \cdot 2$ $\mathrm{ml}$ ) of an appropriate dilution of yellow fever vaccine suspension was mixed with one volume of heat inactivated $\left(56^{\circ} \mathrm{C} / 30 \mathrm{~min}\right)$ human serum diluted, $1: 10,1: 40$, $1: 160$ and $1: 640$, and the serum virus mixtures were held in the wells of plastic plates overnight at $4{ }^{\circ} \mathrm{C}$. Two volumes of PS cells $\left(0.4 \mathrm{ml}\right.$ of $\left.3 \times 10^{5} / \mathrm{ml}\right)$ were then added, and the mixtures incubated at $35^{\circ} \mathrm{C}$ for 2 hs after which $0.4 \mathrm{ml}$ of carboxymethyl cellulose overlay was added to each well, and the preparations incubated at $35^{\circ} \mathrm{C}$ for 5-7 days. Confluent or semi-confluent plaques developed in 
the absence of yellow-fever neutralizing antibodies; sera which reduced the plaque count to below $50 \%$ of that produced in control wells were recorded as positive.

\section{INTERFERON PRODUCTION IN VITRO}

From each subject $20-25 \mathrm{ml}$ of venous blood with phenol-free heparin $(30 \mathrm{iu} / \mathrm{ml})$ were placed in a vessel to which $6 \%$ dextran $(4$ to $5 \mathrm{ml}$ ) was added. Ten millilitre portions in sterile screw-capped tubes were inclined at $45^{\circ}$ and incubated at $37^{\circ} \mathrm{C}$ for $40 \mathrm{~min}$. The plasma was then removed, pooled, and centrifuged at $1000 \mathrm{rpm}$ for $10 \mathrm{~min}$ at room temperature. The leucocyte containing sediment was suspended in Eagles media plus 10\% foetal calf serum. Cell counts were adjusted to $3 \times 10^{6}$ cells $/ \mathrm{ml}$ in screw-capped tubes and inocculated with $0.2 \mathrm{ml}$ of undiluted allantoic fluid containing Newcastle Disease Virus (NDV1) with viral hemagglutinin titres of $1 / 640$ or greater. After $24-\mathrm{h}$ incubation in a roller drum at $37^{\circ} \mathrm{C}$ the fluid was harvested for interferon assay.

Interferon was assayed on fluid dilution by assessment of inhibition of rhinovirus cytopathic effects on WI38 human diploid lung cells utilizing the method of Wheelock. ${ }^{6}$ In each test a standard interferon preparation was incorporated.

\section{Results}

\section{VIRAEMIA}

The results are presented in Table 1. Some early sera were toxic to the cell cultures; consequently it was impossible to detect viraemia in these samples. As expected, viraemia was never present on day 0 , but was present in 6 samples on day 4, in 26 samples on day 5 , and in 15 samples on day 6 . Viraemia was detected at least once in $10 / 12$ normal subjects, in 8/12 patients with lepromatous leprosy and in $9 / 12$ patients with tuberculoid leprosy. There were no significant differences between these three groups in the time of appearance, duration or magnitude of the viraemia.

\section{YELLOW FEVER ANTIBODY}

The results are presented in Table 1. Neutralizing antibody titres of 10 or less were regarded as negative, and titres of 20 and above as positive. By these criteria, 9 of the pre-vaccination samples (day 0 ) appeared to have neutralizing antibodies against yellow fever virus. Since none of the subjects had received prior yellow fever vaccine, and since yellow fever does not occur in nature in Asia, these positive findings presumably reflect cross-protection produced by antibodies 
Table 1.

\begin{tabular}{|c|c|c|c|c|c|c|c|c|c|c|}
\hline \multirow{2}{*}{$\begin{array}{l}\text { Clinicopathologic } \\
\text { classification }\end{array}$} & \multirow{2}{*}{$\begin{array}{c}\text { Mitsuda } \\
\pm \text { (induration) }\end{array}$} & \multicolumn{4}{|c|}{$\begin{array}{c}\text { Yellow Fever viraemia* } \\
\text { days }\end{array}$} & \multicolumn{4}{|c|}{$\begin{array}{l}\text { Yellow Fever antibody } \\
\text { days }\end{array}$} & \multirow{2}{*}{$\begin{array}{r}\text { Newcastle Di } \\
\text { induction of } \\
\text { interferon (re } \\
\text { plaque for }\end{array}$} \\
\hline & & 0 & 4 & 5 & 6 & 0 & 4 & 5 & 12 & \\
\hline \multicolumn{11}{|l|}{ All L } \\
\hline$(\# 12) \mathrm{L}$ & $-(5)$ & $?$ & $?$ & 20 & 10 & 10 & 10 & $<10$ & 20 & $10^{-3}$ \\
\hline$(\# 14) \mathrm{L}$ & $-(0)$ & 0 & 0 & 0 & 0 & $<10$ & $<10$ & 10 & 80 & $10^{-25}$ \\
\hline$(\# 15) \mathrm{BL}$ & $-(5)$ & 0 & SC & 5 & 20 & 10 & 10 & 10 & 80 & $10^{-1.85}$ \\
\hline$(\# 17) \mathrm{L}$ & $+(9)$ & 0 & 0 & 0 & 0 & $<10$ & $<10$ & 10 & 80 & $10^{-225}$ \\
\hline$(\# 18) \mathrm{BL}$ & $-(5)$ & $?$ & $?$ & 10 & 15 & 10 & $<10$ & $<10$ & 80 & $10^{-3}$ \\
\hline$(\# 27) \mathrm{BB} / \mathrm{BL}$ & $-(0)$ & 0 & 0 & 0 & & $<10$ & $<10$ & $<10$ & 20 & $10^{-21}$ \\
\hline$(\# 28) \mathrm{L}$ & $-(5)$ & 0 & Conf & 10 & & $<10$ & $<10$ & $<10$ & 40 & $10^{-2 \cdot 27}$ \\
\hline$(\# 29) \mathrm{BL}$ & $+(8)$ & 0 & 0 & 3 & & 20 & 20 & 20 & 40 & $10^{-2 \cdot 9}$ \\
\hline$(\# 31) \mathrm{BL}$ & $-(0)$ & 0 & 0 & 4 & & 20 & 20 & 20 & 80 & $10^{-3.25}$ \\
\hline$(\# 32) \mathrm{L}$ & $-(2)$ & $?$ & $?$ & 15 & & 20 & 20 & 20 & 20 & $10^{-2 \cdot 7}$ \\
\hline$(\# 33) \mathrm{L}$ & lacking & $?$ & $?$ & 15 & & 20 & 20 & NT & 20 & $10^{-2 \cdot 3}$ \\
\hline$(\# 35) \mathrm{L}$ & $-(0)$ & $?$ & $?$ & 0 & & 10 & 10 & 10 & 40 & $10^{-2 \cdot 5}$ \\
\hline
\end{tabular}




\begin{tabular}{|c|c|c|c|c|c|c|c|c|c|c|}
\hline \multicolumn{11}{|l|}{ All T } \\
\hline (\#1) BT & $-(3)$ & & & 20 & 5 & NT & NT & $<10$ & 10 & $10^{-3}$ \\
\hline$(\# 9) \mathrm{T}$ & lacking & & & 4 & 3 & NT & NT & $<10$ & 20 & $10^{-2}$ \\
\hline$(\# 10) \mathrm{T}$ & $+(14)$ & & & 0 & 0 & NT & NT & 10 & 40 & $10^{-2 \cdot 8}$ \\
\hline$(\# 11) \mathrm{BT}$ & $+(10)$ & 0 & SC & 12 & 10 & 20 & $<10$ & 10 & 20 & $10^{-3 \cdot 5}$ \\
\hline (\#13) $\mathrm{T}$ & $+(8)$ & $?$ & $?$ & 3 & 8 & 10 & 10 & 10 & 20 & $10^{-2 \cdot 7}$ \\
\hline$(\# 16) \mathrm{T}$ & lacking & 0 & Conf & 10 & 10 & 20 & 20 & 20 & 20 & $10^{-3}$ \\
\hline (\#19) BT & $-(4)$ & 0 & 0 & 0 & 0 & $<10$ & $<10$ & $<10$ & 80 & $10^{-3 \cdot 15}$ \\
\hline$(\# 21) \mathrm{T}$ & $+(10)$ & 0 & SC & 0 & & $<10$ & $<10$ & $<10$ & 80 & $10^{-2-1}$ \\
\hline$(\# 23) \mathrm{T}$ & $+(14)$ & $?$ & $?$ & 20 & & 20 & 20 & 20 & 40 & $10^{-2}$ \\
\hline$(\# 25) \mathrm{T}$ & $+(12)$ & 0 & 0 & 10 & & $<10$ & $<10$ & $<10$ & 20 & $10^{-2 \cdot 7}$ \\
\hline$(\# 26) \mathrm{BT}$ & $+(9)$ & 0 & 0 & 3 & & $<10$ & $<10$ & $<10$ & 80 & $10^{-2.75}$ \\
\hline$(\# 34) \mathrm{T}$ & $+(11)$ & 0 & 0 & 0 & & 10 & 10 & 10 & 20 & $10^{-+3}$ \\
\hline \multicolumn{11}{|l|}{ All normal } \\
\hline$(\# 2)$ & $+(10)$ & 0 & 0 & 10 & 2 & $<10$ & $<10$ & $<10$ & 40 & $10^{-2}$ \\
\hline (\#3) & $+(18)$ & $?$ & $?$ & 8 & 10 & $<10$ & $<10$ & $<10$ & 10 & $10^{-2 \cdot 4}$ \\
\hline (\#4) & $+(7)$ & $?$ & $?$ & 20 & 20 & 10 & 10 & 10 & 40 & $10^{-2}$ \\
\hline$(\# 5)$ & $+(9)$ & & & Conf & 2 & NT & NT & 10 & 40 & $10^{-33}$ \\
\hline$(\# 6)$ & $+(9)$ & 0 & 0 & SC & SC & 10 & $<10$ & $<10$ & 10 & $10^{-3 \cdot 15}$ \\
\hline$(\# 7)$ & $+(10)$ & 0 & 0 & 5 & 3 & $<10$ & $<10$ & $<10$ & 40 & $10^{-3 \cdot 5}$ \\
\hline$(\# 8)$ & $+(20)$ & & & Conf & Conf & NT & NT & $<10$ & 20 & $10^{-2 \cdot 35}$ \\
\hline$(\# 20)$ & $+(12)$ & $?$ & $?$ & 0 & & $<10$ & 10 & 10 & 20 & $10^{-2}$ \\
\hline$(\# 22)$ & $+(10)$ & 0 & Conf & 5 & & 20 & 20 & $>20$ & 80 & $10^{-2 \cdot 2}$ \\
\hline$(\# 24)$ & $+(9)$ & 0 & 0 & 0 & & $<10$ & $<10$ & $<10$ & 80 & $10^{-2}$ \\
\hline$(\# 30)$ & $+(10)$ & 0 & 0 & 8 & & 20 & 20 & 20 & 40 & $10^{-3}$ \\
\hline$(\# 36)$ & lacking & $?$ & $?$ & 1 & & 10 & $<10$ & 10 & 40 & $10^{-2 \cdot 3}$ \\
\hline
\end{tabular}

?, toxic; SC, semi-confluent; Conf, confluent: *, plaques per $0 \cdot 1 \mathrm{ml}$ serum; NT, not tested. 
against antigenically related flaviviruses which do occur in Malaysia, of which dengue and Japanese encephalitis viruses are the two most probable candidates. The day 4 and day 5 samples gave results virtually indistinguishable from those obtained with the day 0 samples, but by day 12 only 3 sera remained antibody negative, and these came from subjects who were viraemic on days 5 and 6 . Antibody titres tended to be higher in the lepromatous leprosy patients than in the other groups. All the subjects who failed to produce a detectable viraemia nevertheless responded with the production of yellow fever antibodies.

\section{INTERFERON PROIDUCCTION IN VITRO}

All of the subjects studied produced significant amounts of interferon in vitro following stimulation of peripheral blood leucocyte cultures. For normal subjects

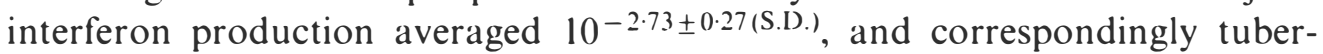
culoid patients $10^{-2} 95 \pm 0.30^{\circ}$ (S.I.). , and lepromatous patients $10^{-2.55 \pm 0.18(\text { S.D.). }}$. These differences in interferon production between the three groups of patients were not significant. However, lepromatous subjects' interferon production was less than tuberculoid patients' $(P=0 \cdot 06)$.

\section{Discussion}

Wheelock et al. ${ }^{7}$ demonstrated previously that viraemia could be identified in 10 of 15 normal subjects following vaccination with the 17-D strain of yellow fever virus, and by 10 days following vaccination, yellow fever antibody was detectable in all the subjects. These current studies are in essential accord with those findings. In our studies the titre and period of viraemia, following viral challenge in vivo and the production of specific neutralizing antibody appears to be normally generated in both lepromatous and tuberculoid patients. Also, these studies demonstrate that production of interferon to viral challenge by peripheral blood mononuclear cells in vitro in leprosy patients across the spectrum, does not appear aberrant. Control of viral infection involves a complex network which includes antibody, cellular immunity, and interferon which act in an integrated manner. These studies support that in leprosy patients this network is generally intact.

Though patients with lepromatous leprosy are known to produce a polyclonal hyperglobulinemia ${ }^{8-11}$ that can result in a wide variety of falsely positive serologic tests, ${ }^{12-16}$ antibody production in leprosy is not, however, conceived to be generally aberrant. In fact lepromatous patients were found to produce higher titres of agglutinins to $\mathrm{H}$-antigens, in response to typhoid vaccine, than healthy military recruits. ${ }^{17}$ Indeed, antibody to a Mycobacterium leprae-specific phenolic glycolipid is regularly produced in lepromatous leprosy and in high titre. ${ }^{18}$ Our studies further support the concept that antibody to specific pathogens is not abnormally generated in leprosy patients. 
Glasgow and Bullock ${ }^{19}$ previously demonstrated that mice heavily infected with $M$. lepraemurium following intraperitoneal challenge with chikungunya virus produced distinctly lower levels of interferon than control mice, uninfected with $M$. lepraemurium. Mixed peritoneal cells from infected mice also reflected these in vivo findings and demonstrated decreased interferon production to chikungunya virus. It has been postulated that human lepromatous leprosy might also be associated with a defect of interferon producing capacity or other responses to viral challenges. In this respect a number of clinical reports have indeed suggested that lepromatous leprosy patients are more susceptible to variola $^{20}$ and demonstrate slow resolution of inoculation lesions and vaccinia gangrenosa following vaccination, ${ }^{21.22}$ an indication of impaired cellular immunity. The present study found leprosy patients had no observed aberrancy in protective immunity to yellow fever. The decreased production of interferon in vitro by lepromatous as compared to tuberculoid patients $(P=0.06)$ found in these studies is, however, of some interest.

Though interferon production has been classically considered to be induced by viruses, parasites, ${ }^{23-26}$ and bacterial products, including endotoxin ${ }^{27-30}$ tuberculin, ${ }^{31}$ and poly RI-poly IC ${ }^{32-35}$ are potent interferon inducers. Interferon has also been shown to inhibit in vivo multiplication of various intra- and extracellular pathogens other than viruses including pneumococci, ${ }^{36}$ listeria, ${ }^{37}$ trachoma,${ }^{38}$ cryptococcus, ${ }^{19} \mathrm{P}$. berghei, ${ }^{39}$ and certain tumours not known to be caused by viruses. ${ }^{40}$ Levy et al. ${ }^{41}$ found that the potent interferon inducers poly IC and Tilerone inhibited mouse footpad multiplication of $M$. leprae. Nogueira et $a l .{ }^{42}$ found peripheral blood mononuclear cells from lepromatous leprosy patients, even those on long-term therapy, deficient in their capacity to release gamma interferon in vivo in response to both mitogen and $M$. leprae. In those studies interleukin 2 was found to restore the decreased gamma interferon production of lepromatous leprosy in response to specific antigen or mitogen. Gamma interferon is evoked by specific cellular memory and these studies do not clarify if this fraction, especially that induced by $M$. leprae and potentially protective, is deficient.

There is considerable evidence on both sides of the issue of whether the immune defect in lepromatous leprosy is due to a specific defect ${ }^{43-46}$ in host defence mechanisms against $M$. leprae or secondary to some more generalized anergy. ${ }^{47-51}$ There has also been conjecture that certain individuals are genetically incapable of mounting an appropriate protective response thereby being predisposed to the development of leprosy, or alternatively, that the development of leprosy is due entirely to environmental exposure to the bacillus, wherein possibly the timing, route, and degree of exposure are crucial factors in determining whether overt disease does or does not become manifest. Certainly these two propositions need not be mutually exclusive and most likely both heredity and environmental factors interplay to determine the outcome in 
individuals exposed to $M$. leprae. In any event these current studies lend support to the concept that leprosy patients do not present a generalized immune defect.

\section{Acknowledgments}

We wish to gratefully acknowledge the Institute for Medical Research, Malaysia and the Malaysian Ministry of Health for their support of this project.

\section{References}

I Sansonetti P, Lagrange PH. The immunology of leprosy. Speculations on the leprosy spectrum. Rev Inf Dis, 1981; Vol. 3, 422-469.

2 Purtilo DT, Pangi C. Incidence of cancer in patients with leprosy. Cancer, 1975; 35: 1259-1261.

${ }^{3}$ Olenic A. Altered immunity and cancer risk: a review of the problem and analysis of the cancer mortality experience of leprosy patients. $J$ Nat Cancer Inst, 1969; 43: 775-781.

4 Turk JL, Waters MFR. Leprosy. In: Immunological diseases. Samter M (ed), 3rd ed, 1978. Little Brown, Boston, Vol. 1, 627-638.

5 Madrid AT, Porterfield JS. 'A simple micro-culture method for the study of group B arboviruses'. Bull World Health Organization, 1969; 40: 113-121.

- Wheclock EF. Virus replication and high-titred interferon production in human leukocyte cultures inoculated with Newcastle Disease Virus. J Bact, 1966; 92: 1415-1421.

7 Wheclock EF, Sibley WA. Circulating virus, interferon and antibody after vaccination with the 17-D strain of yellow-fever virus. N EJ M, 1965; Vol. 273, 194-201.

\& Bullock WE, Ho MF, Chen MJ. Studies of immune mechanisms in leprosy. J Lah Clin Med, 1970; 75: 863-870.

9 Waters MFR, Turk JL, Wemambu SNC. Mechanisms of reactions in leprosy. Int J Lepr, 1971; 39: $417-428$.

10 Jha P, Balakrishnan K, Talwar GP, Bhutani LK. Studies of humoral immune response in leprosy. Int J Lepr, 1970; 39: 14-19.

"Sheagren JN, Block JB, Trauttian JR, Wolff SM. Immunologic reactivity in patients with leprosy. Ann Intern Med, 1969; 70: 295-302.

12 Abe M, Chinone S, Hirako T. Rheumatoid-factor-like substance and antistreptolysin $\mathrm{O}$ antibody in leprosy serum: Significance in erythema nodosum leprosum. Int J Lepr, 1967; 35: 336.

13 Bonono L, Dammacco F, Pinto L, Barbieri G. Thyroglobulin antibodies in leprosy. Lancet, 1963; 2: 807.

14 Bonono L, Tursi A, Trimigliozzi G, Dammacco F. LE cells and antinuclear factors in leprosy. $\mathrm{Br}$ Med J, 1965; 2: 689.

15 Cannefax GR, Ross H, Bancroft H. Reactivity of the RPCF test in leprosy compared with other syphilis tests. $J$ Pub Health Rep, 1959; 74: 45.

${ }^{16}$ Cathcart ES, Williams RC, Ross H, Calkins E. The relationship of the latex fixation test to the clinical and serologic manifestations of leprosy. Amer J Med, 1961; 31: 758.

17 De Almeida JO, Brandao H, de Lima EG. Enhanced serologic response of lepromatous patients to antityphoid vaccination. Int J Lepr, 1964; 32: 292-296.

${ }^{18}$ Cho Sang-Nae, Yanagihara Donna L, Hunter SW, Gelber RH, Brennan PJ. Serological specificity of phenolic glycolipid I from Mycohacterium leprae and use in serodiagnosis of leprosy. Infect and Immunity, 1983; Vol. 41, 1077-1083. 
19 Glasgow LA, Bullock WE. Impairment of interferon production in mice infected with Mycobacterium lepraemurium. Proc Soc Exp Biol Med, 1972; 139: 492-496.

${ }^{20}$ Denney OE, Hopkins R. 'Specific leprous reactions and abnormal vaccin-induced in leprosy by smallpox vaccination'. J Pub Health Rev, 1922; 37: 3141-3143.

${ }^{21}$ Browne SG, Davis EM. 'Reaction in leprosy precipitants by smallpox vaccination'. Lepr Rev, 1962; 11: 252-387.

${ }^{22}$ Saha K, Mittal ML, Ray SN. Consequences of small pox vaccination in leprosy patients. Infect Immun, 1973; 8: 301-308.

${ }^{23}$ Rytel MW, Jones TC. Induction of interferon in mice infected with Toxoplasma gondii. Proc Soc Exp Biol Med, 1966; 123: 859-862.

${ }^{24}$ Freshman MM, Merigan TC, Remington JS et al. In vitro and in vivo antiviral action of an interferon-like substance induced by Toxoplasma gondii. Proc Soc Exp Biol Med, 1966; 123: $862-866$.

${ }^{25}$ Huang K-Y, Schultz WW, Gordon FB. Interferon induced by Plasmodium berghei. Science, 1968; 162: 123-124.

26 Rytel MW, Marsden PD. Induction of an interferon-like inhibitor by Trypanosoma cruzi infection in mice. Am J Trop Med Hyg, 1970; 19: 929-931.

27 Stinebring WR, Youngner JS. Patterns of interferon appearance in mice infected with bacteria or bacterial endotoxin. Nature (Lond), 1964; 204: 712.

${ }^{28}$ Ho M. Interferon-like viral inhibitor in rabbits after intravenous administration of endotoxin. Science, 1964; 146: 1472-1474.

29 Youngner JS, Stinebring WR. Interferon appearance stimulated by endotoxin, bacteria, or viruses in mice pretreated with Escherichia coli endotoxin or infected with Mycobacterium tuberculosis. Nature (Lond), 1965; 208: 456-458.

${ }^{30}$ deSomer P, Billiau A. Interferon production by the spleen of rats after intravenous injection of Sindbis virus or heat-killed Escherichia coli. Arch Gesamte Virusforsch, 1966; 19: 143-154.

${ }^{31}$ Green JA, Cooperband SR, Kibrick S. Immune specific induction of interferon production in cultures of human blood lymphocytes. Science, 1969; 164: 1415-1417.

${ }^{32}$ Hilleman MR. Double-stranded RNAs (Poly $1:$ C) in the prevention of viral infections. Arch Int Med, 1970; 126: 109-124.

${ }^{33}$ Colby C, Duesberg PH. Double-stranded RNA in vaccinia virus infected cells. Nature (Lond), 1969; 222: 940-944.

${ }^{34}$ DeMaeyer E, DeMaeyer-Guignard J, Montagnier L. Double stranded RNA from rat liver induces interferon in rat cells. Nature (New Biol) (Lond), 1970; 229: 219-222.

${ }^{35}$ Merigan TC. Interferon stimulated by double-stranded RNA. Nature (Lond), 1970; 228: 219222.

${ }^{36}$ Regelson W, Munson A. The reticuloendothelial effects of interferon inducers: polyanionic and non-polyanionic phylaxis against microorganisms. Ann NY Acad Sci, 1970; 173: 831-841.

37 Vilcek, J, Jahiel RI. Action of interferon and its inducers against nonviral infectious agents. Arch Int Med, 1970; 126: 69-77.

${ }^{38}$ Hanna L, Merigan TC, Jawetz E. Effect of interferon on TR IC agents and induction of interferon by TRIC agents. Am J Ophthal, 1967; 63: 1115-1119.

39 Jahiel RI, Vilcek J, Nussenzweig RS. Exogenous interferon protects mice against plasmodium berghei malaria. Nature (Lond), 1970; 227: 1350-1351.

${ }^{40}$ Levy HB, Law LW, Rabson AS. Inhibition of tumour growth by polyinosinic-polycytidylic acid. Proc Natl Acad Sci USA, 1969; 62: 357-361.

${ }^{41}$ Levy L, Aizer F, Ng H, Welch TM. The effects of tilorone on mycobacterial infections of mice. Lepr Rev, 1978; 49: 215-222.

${ }^{42}$ Nogueira N, Kaplan G, Levy E, Sarno EN, Kushner P, Granelli-Piperno L, Vieira L, Gould VC, Levis W, Steinman R, Yip YK, Cohn ZA. Defective interferon production in leprosy. Reversal with antigen and interleukin 2. J Exp Med, 1983; 158: 2165-2170. 


\section{$164 \quad R$ Helber et al.}

${ }^{43}$ Mohagheghpour N, Gelber RH, Larrick JW, Sasaki DT, Brennan PJ, Engleman EG. Defective cell-mediated immunity in leprosy: failure of $\mathrm{T}$ cells from lepromatous leprosy patients to respond to mycobacterium leprae is associated with defective expression of interleukin 2 receptors and is not reconstituted by interleukin 2. J Immun, 1985; Vol. 135, 1443-1449.

44 Rea TH, Quismorio FP, Harding B, et al. Immunologic responses in patients with lepromatous leprosy. Arch Dermatol, 1976; 112: 791-800.

${ }^{45}$ Convit J, Pinardi ME, Rojas FA. Some considerations regarding the immunology of leprosy. Int $J$ Lepr, 1971; 39: 556-564.

${ }^{46}$ Ulrich M, deSalas $\mathrm{B}$, Convit J. Lymphocyte transformation with phytomitogens in leprosy. Int $J$ Lepr, 1972; 40: 4-9.

47 Talwar GP, Krishnan AD, Mehra VL, et al. Evaluation of cell-mediated immune responses in untreated cases of leprosy. Clin Exp Imm, 1972; 12: 195-203.

${ }^{48}$ Bullock WE. Studies of immune mechanisms in leprosy: 1. Depression of delayed allergic responses to skin test antigens. $N$ Engl J Med, 1968; 278: 298-304.

49 Turk JL, Waters MFR. Cell-mediated immunity in patients with leprosy. Lancet, 1969; 2: 243246.

${ }^{50}$ Mehra VL, Talwar GP, Balakrishnan K, Bhutani LK. Influence of chemotherapy and serum factors on the mitogenic response of peripheral leucocytes of leprosy patients to phytohemagglutinin. Clin Exp Imm, 1972; 12: 205-213.

51 Nath I, Curtis J, Bhutani LK, Talwar GP. Reproduction of a subpopulation of T lymphocytes in lepromatous leprosy. Clin Exp Imm, 1974; 18: 81-87. 